\title{
Mapping and Assessment of Ethno- Medicinal Trees in Built Up Areas - University of Port Harcourt, Nigeria
}

\author{
Olatunde Sunday Eludoyin ${ }^{1 \Xi}$, Adekunle Tajudeen Oladele ${ }^{2}$, \\ Oluwatosin Muhibudeen lyanda ${ }^{1}$
}

\begin{abstract}
${ }^{1}$ University of Port Harcourt, Faculty of Social Sciences, Department of Geography and Environmental Management, East/West Road PMB, NG-5323 Choba, Rivers State, Nigeria

2 University of Port Harcourt, Faculty of Agriculture, Department of Forest and Wildlife Management, East/West Road PMB, NG-5323 Choba, Rivers State, Nigeria
\end{abstract}

$\triangle$ Corresponding author: e-mail: olatunde.eludoyin@uniport.edu.ng

Citation:

ELUDOYIN OS, OLADELE AT, IYANDA OM 2015 Mapping and Assessment of Ethno-Medicinal Trees in Built Up Areas - University of Port Harcourt, Nigeria. South-east Eur for 6 (1): 129-140. DOI: http://dx.doi.org/10.15177/seefor.15-10

\section{Abstract}

Background and Purpose: Several urban tree species are important in ethno-medicine, especially in the developing tropical regions. Their assessment in urban landscapes is becoming an important issue. The study assessed and mapped the ethno-medicinal trees in the built up area land use type of the University of Port Harcourt, Nigeria, with a view to examining their spatial variation in terms of composition and diversity between the residential and non-residential areas of the University Park. Materials and Methods: The study employed the use of geographic information system (ArcGIS 9.3) for the mapping. Built up area land use was subdivided into residential and non-residential where the ethno-medicinal trees were recorded, identified and enumerated. Global positioning system was used to determine the coordinates of each tree. The species composition and diversity were calculated and a comparison was made between the residential and non-residential land use types. The pattern of spread of the ethno-medicinal trees was determined by the nearest neighbour analysis.

Results: A total of 37 ethno-medicinal trees species were found in the study area, while the species composition was 499 in the residential area and 438 in the non-residential area. Azadirachta indica was the highest (233) in composition. Ethno-medicinal tree species in the study area consist of 19 families of which Anacardiaceae, Rutaceae, Moraceae and Combretaceae were the highest. Species diversity was higher in the non-residential land use (2.698) than in the residential land use (2.222).

Conclusion: The nearest neighbour analysis reveals that the z-score value was higher in the nonresidential area $(-23.06)$ than in the residential area $(-0.30)$, but the pattern of distribution in both areas were clustered. The study recommended periodic monitoring and the assessment of ethnomedicinal trees in the study area for conservation purposes.

Keywords: geographic information systems, nearest neighbour analysis, urban forestry, species diversity, species richness, species evenness 


\section{INTRODUCTION}

The assessment of ethno-medicinal plants in urban landscapes is becoming an important issue, especially in the developing world, where many of these plant species are being used as avenue [1] and ornamental trees. Urban forestry integrating ethno-medicinal plants is particularly beneficial to mankind and its importance cannot be underestimated, especially in this era, when the developing countries are witnessing tremendous changes [2, 3]. However, Ajewole [4] explained that urban forestry is a planned, integrated and systematic approach to the management of trees and woodland/forest resources in urban and peri-urban areas for their contributions to the physiological, sociological, psychological and economic well-being of the urban society.

Since the first earth summit in Rio de Janeiro, there has been a sustained global awareness of the importance of the superfluity of biodiversity and natural resources from tropical forests for several purposes, which included the potent ethno-botanical uses of the plants in these forests [5]. World Health Organization (WHO) [6] reported that about $80 \%$ of the population in the developing countries depends on medicinal plants in the treatment of diseases, and that medicinal plants represented a primary health source for the pharmaceutical industry. Hence, WHO produced guidelines for the global use of traditional medicine. According to Dambatta and Aliyu [7], the use of herbal medicine in Nigeria represents a long history of human interaction with the environment, and the plants used in traditional medicine contain a wide range of substances that can be used to treat chronic as well as infectious diseases. Nwauzoma and Dappa [8] noted that herbal or traditional medicine has been a major aspect of the sociocultural heritage in Africa for hundreds of years even before the advent of conventional medicine. In addition, Wahab et al. [9] reported that the use of medicinal plants as a source of relief from illness is as old as mankind. As a result, the ethno-medicinal plants require adequate and periodic monitoring and assessment which can help to understand their structures (the diameter at breast height - $d b h$, species composition, tree height, crown spread, biomass and tree location) [10] and aid their environmental sustainability for use and human survival in such societies.

The application of geographic information system (GIS) in phenomenon location has been well spelt in various spatial-related studies and this can be extended to urban forestry. According to Wood [11], GIS in urban forestry has long been recognized as a useful tool in the management of natural resource development, land use planning, wildlife management, environmental planning and forestry planning. Miller [12] also noted that urban tree mapping and inventories are key areas that can be greatly enhanced by GIS. GIS is therefore a tool that gives urban foresters and planners the ability to manage and predict the future growth of the urban forests in a better way $[11,13]$.

There are several studies on ethno-medicinal trees in Nigeria [8, 9, 14-16]. The majority of these studies used a questionnaire to carry out the inventory on ethno-medicinal trees. The inventories were not carried out within an institution, except in the work of Jimoh et al. [17] in the University of Agriculture Campus, Makurdi, Nigeria. The mapping of ethno-medicinal trees with the use of geo-information technologies such as GIS in natural forest and agro-ecosystem was carried out in Pakistan and Spain [18, 19], but such work is rare, especially in institutionalbased environment, such as universities, research Institutes and teaching hospitals globally. This study therefore focused on mapping and assessing the ethno-medicinal trees within the University Park of the University of Port-Harcourt with a view to examining their spatial variation in terms of composition and diversity between the residential and non-residential areas of the Park.

\section{MATERIALS AND METHODS}

\section{Study Area}

The research was conducted in the University Park, University of Port Harcourt, Port Harcourt, Nigeria. Covering the total area of 461 ha the University Park extends from 04 $52^{\prime} 30^{\prime \prime}$ to 
$04^{\circ} 55^{\prime} 00^{\prime \prime}$ north latitude and from 06 $54^{\prime} 40^{\prime \prime}$ to $06^{\circ} 55^{\prime} 40^{\prime \prime}$ east longitude (Figure 1). Port Harcourt is situated in subequatorial region. A moist south-west wind and northeast trade winds are responsible for the variations in weather conditions experienced in Port Harcourt City. The moist south-east air stream blows over the region between February and November and the region receives its rains, while the northeast trade wind blows over Port Harcourt in from November up to February, which ushers in the dry season. Port Harcourt records a mean annual temperature of $28^{\circ} \mathrm{C}$; relative humidity is generally high over Port Harcourt with a mean annual figure of $85 \%$. The peak of rainy season usually occurs from June to October, with the total annual rainfall of more than $2500 \mathrm{~mm}$. The soil of Port Harcourt city is of the recent alluvial soil. Port Harcourt is dominated by low-lying coastal plains which structurally belong to the sedimentary formation of recent Niger delta, with an elevation less than $15.24 \mathrm{~m}$.

\section{Land Use Map Generation}

SPOT imagery of the study area of $2.5 \mathrm{~m}$ $x 2.5 \mathrm{~m}$ spatial resolution was acquired from Google Earth, 2013 version to generate the land use map. The imagery was geo-referenced in ArcGIS 9.3 to world geographic coordinate system (WGS 84). Land use types were captured in polygons from which built up area land use was dissolved. The built up area land use for this study was further subdivided into the residential area and the non-residential area.

\section{Tree Mapping Generation}

The coordinates (i.e. latitudes and longitudes) of all ethno-medicinal trees in the built up area of the University Park were recorded by global positioning system (GPS) of Garmin eTrex 30 with the precision level of $\pm 7 \mathrm{~m}$. An experienced traditional healer was assisted in identifying the ethno-medicinal uses of the recorded tree species. Tree specimens were collected, identified, pressed and deposited in the herbarium

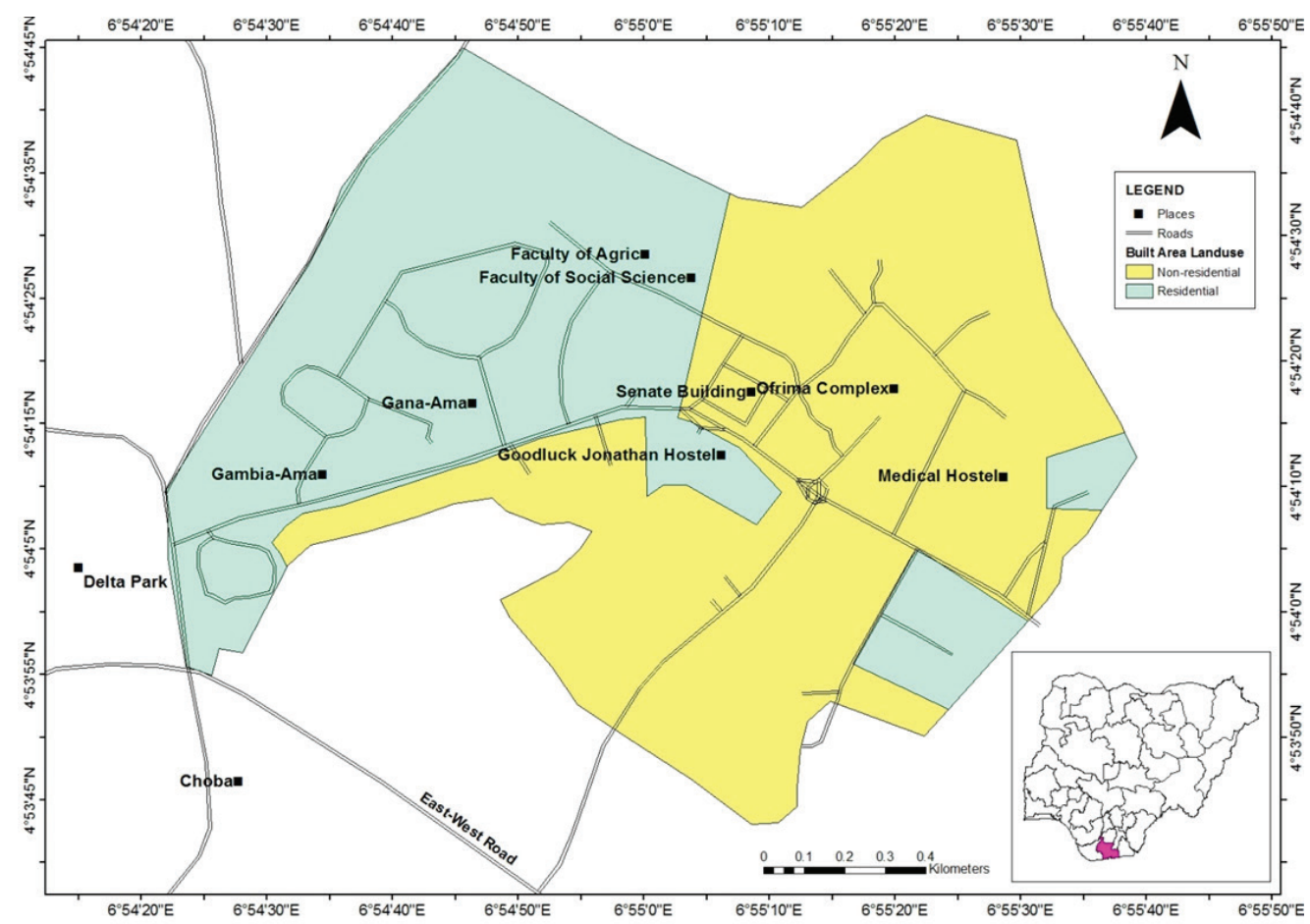

FIGURE 1. Map of University Park, University of Port Harcourt 
of the Department of Forestry and Wildlife Management, University of Port Harcourt, for referencing. The recorded coordinates were imported to ArcGIS 9.3 for mapping.

\section{The Determination of Ethno-Medicinal Tree Diversity, Richness and Evenness}

Tree species diversity index $\left(\mathrm{H}^{\prime}\right)$ was computed using Shannon and Wiener's diversity index, a commonly used index in the literature on biological diversity and ecological monitoring $[20,21]$ :

$$
H^{\prime}=-\sum_{i=1}^{s} p i \ln (p i)
$$

where: $p i$ is the proportion of individuals belonging to the $i$-th species calculated as $\mathrm{pi}=$ $\mathrm{S} / \mathrm{N}$; In is logarithms (base e), $\mathrm{S}$ is the number of individuals of one species, and $\mathrm{N}$ is the total number of all individuals in the sample.

The species richness was determined using Margalef's index [22] expressed as:

$$
D_{m g}=S-1 / \operatorname{lnN}
$$

where: $D_{m g}$ is Margalef's index, $S$ is the number of species, $\mathrm{N}$ is the total number of individuals encountered, and In is the natural logarithm (base e).

Species evenness of ethno-medicinal trees was calculated using Pieolu's index [23] modified by Magurran [24]:

$$
E^{\prime}=H^{\prime} / \ln S
$$

where: $\mathrm{H}^{\prime}$ is the Shannon-Wiener diversity index and $S$ is the number of species. $E^{\prime}$ is constrained between 0 and 1 .

\section{Statistical Analysis}

Descriptive analysis was used to describe the composition and diversity in both residential and non-residential areas of the built up areas. The nearest neighbour analysis was used to determine and compare the pattern of distribution of ethno-medicinal trees in both residential and non-residential land use types using the z-score value. This analysis was performed in ArcGIS 9.3 version.

\section{RESULTS}

\section{Species Composition of Ethno-Medici- nal Trees}

The species composition of ethno-medicinal trees in the residential and non-residential areas of the built up area land use is shown in Table 1. A total of 37 tree species of ethnomedicinal importance were found in the study area. However, the total frequencies of ethnomedicinal trees were 936 of which 499 were in residential and 437 in non-residential areas. Margalef's index showed the ethno-medicinal tree species richness in residential and nonresidential areas of the built up areas in the University Park as 4.0240 and 4.6035 respectively (Table 2). According to the results of the family diversity of ethno-medicinal tree species in the study area (Figure 2), Combretaceae, Anacardiaceae, Caesalpinaceae, Moraceae and Rutaceae families had the highest occurrence of four ethno-medicinal tree species, each in the University Park built up areas. Species representing the four (4) families above possess the ability to perform dual functions of local medicines and edible fruit or shade provision, and therefore they are planted or protected in the built up areas of the university.

\section{Species Diversity of Ethno-Medicinal Trees in the Residential Areas (RAs) and Non-Residental areas (NRAs)}

Species diversity of ethno medicinal trees in the study area is shown in Table 3. Ethnomedicinal tree species were more diversified in NRA (2.6981) than RAs (2.222) due to the fact that NRAs mostly include ornamental trees which may not be given priority in the RAs. Plants used for medicine and food are usually cultivated in home gardens.

\section{Spatial Distribution of Ethno-Medicinal Trees}

Spatial distribution of ethno-medicinal trees (Figure 3 ) revealed that most of the ethnomedicinal trees were found along the roads within the University Park, especially Azadirachta indica A.Juss, which was prominent along the 


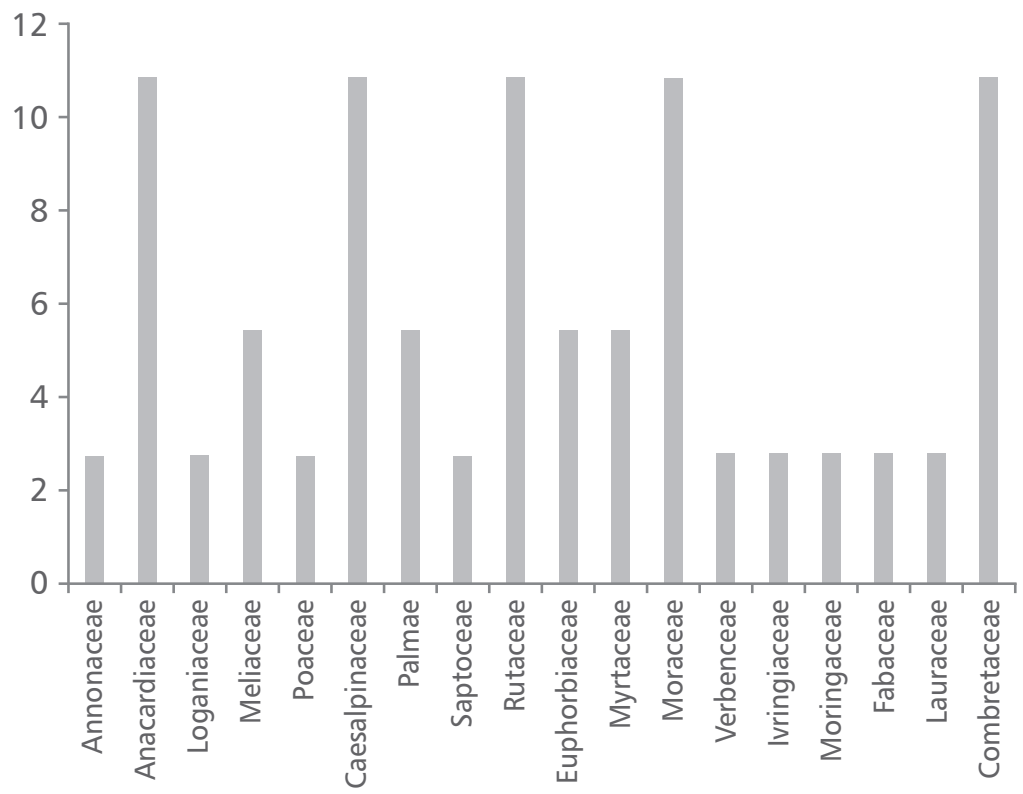

FIGURE 2. Diversity of ethno-medicinal trees in built up areas of University Park, University of Port Harcourt, Nigeria

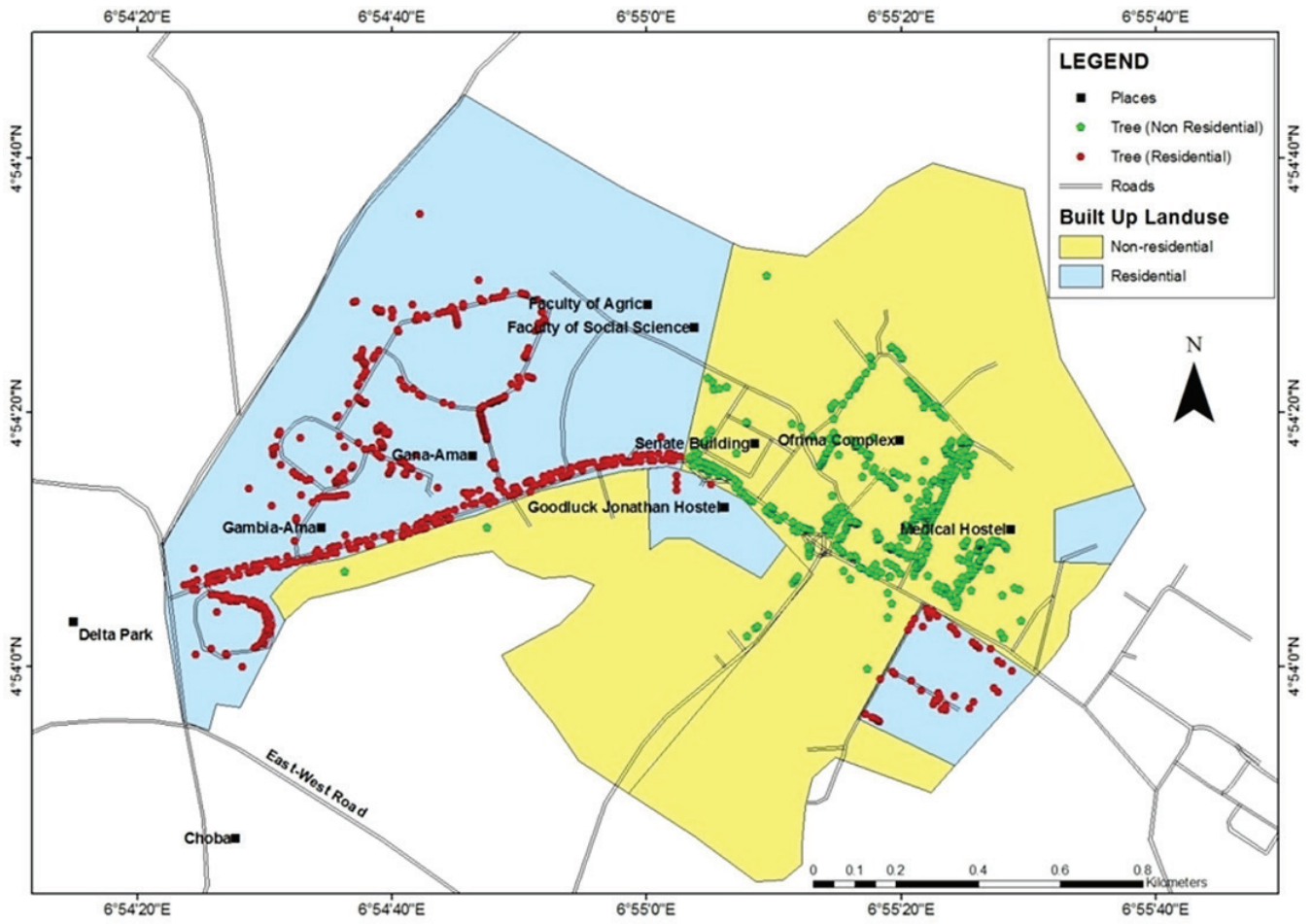

FIGURE 3. Distribution of ethno-medicinal trees in residential and non-residential area 
TABLE 1. Species composition and richness of ethno-medicinal tree

\begin{tabular}{|c|c|c|c|c|c|}
\hline $\mathrm{S} / \mathrm{N}$ & Species & Common name & Local medicinal uses & RA & NRA \\
\hline 1 & $\begin{array}{l}\text { Annona muricata L. } \\
\text { (Annonaceae) }\end{array}$ & Sour sop & $\begin{array}{l}\text { Leaves used to lessen effect of } \\
\text { cancer, fruits eaten as snacks }\end{array}$ & 0 & 2 \\
\hline 2 & $\begin{array}{l}\text { Anacardium occidentale L. } \\
\text { (Anacardiaceae) }\end{array}$ & Cashew & $\begin{array}{l}\text { Diarrhea, diabetes, fruits eaten } \\
\text { as snacks }\end{array}$ & 19 & 14 \\
\hline 3 & $\begin{array}{l}\text { Anthocleista vogelii Planchon. } \\
\text { (Loganiaceae) }\end{array}$ & Cabbage tree & Root used to treat gonorrhea & 1 & 0 \\
\hline 4 & $\begin{array}{l}\text { Azadirachta indica A.Juss } \\
\text { (Meliaceae) }\end{array}$ & Neem tree & $\begin{array}{l}\text { Decoction of leaves and stem } \\
\text { barks as antimalarial }\end{array}$ & 172 & 61 \\
\hline 5 & $\begin{array}{l}\text { Bambussa vulgaris Schrader } \\
\text { ex Wendl. (Gramineae) }\end{array}$ & Bamboo & $\begin{array}{l}\text { Abortifacents, leaves used as } \\
\text { male contraceptives }\end{array}$ & 2 & 0 \\
\hline 6 & $\begin{array}{l}\text { Bauhinia tomentosaL. } \\
\text { (Caesalpinaceae) }\end{array}$ & Yellow Bauhinia & Diarrhea, dysentery and diabetes & 1 & 0 \\
\hline 7 & $\begin{array}{l}\text { Borassus aethiopicum Mart. } \\
\text { (Palmae) }\end{array}$ & African fan palm & $\begin{array}{l}\text { Aphrodisiac, boiled tender roots } \\
\text { as snacks and condiments }\end{array}$ & 3 & 12 \\
\hline 8 & $\begin{array}{l}\text { Chrysophyllum albidum L. } \\
\text { (Sapotaceae) }\end{array}$ & $\begin{array}{l}\text { Cherry/African } \\
\text { star apple }\end{array}$ & Fruits as snacks & 2 & 9 \\
\hline 9 & $\begin{array}{l}\text { Citrus limon (L.) Burm.f. } \\
\text { (Rutaceae) }\end{array}$ & Lemon & $\begin{array}{l}\text { Fruits and leaves used for cough } \\
\text { and malaria }\end{array}$ & 7 & 3 \\
\hline 10 & $\begin{array}{l}\text { Citrus reticulata Blanco } \\
\text { (Rutaceae) }\end{array}$ & Tangerine & $\begin{array}{l}\text { Fruits and leaves used for cough } \\
\text { and malaria }\end{array}$ & 1 & 0 \\
\hline 11 & $\begin{array}{l}\text { Citrus sinensis (L) Osbeck } \\
\text { (Rutaceae) }\end{array}$ & Sweet orange & $\begin{array}{l}\text { Leaves used for cough, } \\
\text { ringworm and malaria }\end{array}$ & 25 & 19 \\
\hline 12 & $\begin{array}{l}\text { Citrus paradisi Macfad. } \\
\text { (Rutaceae) }\end{array}$ & Grape fruit & $\begin{array}{l}\text { Fruits and leaves used for cough } \\
\text { and malaria }\end{array}$ & 0 & 5 \\
\hline 13 & $\begin{array}{l}\text { Crotom zambesicus Mull-Arg. } \\
\text { (Euphorbiaceae) }\end{array}$ & Bushveld & $\begin{array}{l}\text { Root as antidiabetic and } \\
\text { antimalarial }\end{array}$ & 1 & 13 \\
\hline 14 & $\begin{array}{l}\text { Delonix regia (Boj. Ex Hook) } \\
\text { Raf.(Papilionaceae) }\end{array}$ & $\begin{array}{l}\text { Flame of the } \\
\text { forest }\end{array}$ & Anthelminthic/ornamental & 17 & 14 \\
\hline 15 & $\begin{array}{l}\text { Elaeis guineensis Jacq. } \\
\text { (Palmae) }\end{array}$ & Oil Palm tree & Malaria, fruits used for palm oil & 79 & 88 \\
\hline 16 & $\begin{array}{l}\text { Eucalyptus camaldulensis } \\
\text { Dehnh (Myrtaceae) }\end{array}$ & Eucalyptus & Sore throat & 34 & 27 \\
\hline 17 & $\begin{array}{l}\text { Ficus exasperata Vahl. } \\
\text { (Moraceae) }\end{array}$ & Sand paper tree & Wound healing & 1 & 0 \\
\hline 18 & $\begin{array}{l}\text { Ficus mucoso Welw. } \\
\text { (Moraceae) }\end{array}$ & Fig tree & Snake bite & 0 & 2 \\
\hline 19 & Ficus sur Forssk. (Moraceae) & Wild fig & Wound healing & 0 & 1 \\
\hline 20 & $\begin{array}{l}\text { Gmelina arborea L. Roxb. } \\
\text { (Verbanaceae) }\end{array}$ & Gmelina & Wound healing & 10 & 8 \\
\hline 21 & $\begin{array}{l}\text { Hura crepitans L. } \\
\text { (Euphorbiaceae) }\end{array}$ & Sandbox tree & Purgatives & 12 & 32 \\
\hline 22 & $\begin{array}{l}\text { Irvingia gabonensis (Aubry- } \\
\text { Lecomte ex O’Rorke) Baill. } \\
\text { (Irvingaceae) }\end{array}$ & Wild mango & Food condiment & 2 & 0 \\
\hline 23 & $\begin{array}{l}\text { Mangifera indica L. } \\
\text { (Anacardiaceae) }\end{array}$ & Mango & $\begin{array}{l}\text { Leaves and stem bark as } \\
\text { antimalarial }\end{array}$ & 60 & 45 \\
\hline 24 & $\begin{array}{l}\text { Milicia excelsa (Welw.) CC } \\
\text { Berg (Moraceae) }\end{array}$ & Iroko & $\begin{array}{l}\text { Malaria, body pain and } \\
\text { antiaging }\end{array}$ & 0 & 4 \\
\hline
\end{tabular}


TABLE 1. Species composition and richness of ethno-medicinal tree - continuation

\begin{tabular}{|c|c|c|c|c|c|}
\hline $\mathrm{S} / \mathrm{N}$ & Species & Common name & Local medicinal uses & RA & NRA \\
\hline 25 & $\begin{array}{l}\text { Moringa olivera Lam. } \\
\text { (Moringaceae) }\end{array}$ & $\begin{array}{l}\text { Moringa, } \\
\text { miracle tree }\end{array}$ & Diabetes and hypertension & 1 & 0 \\
\hline 26 & $\begin{array}{l}\text { Musanga cecropioides R.Br. } \\
\text { ex Tedlie (Cecropiaceae) }\end{array}$ & Umbrella tree & Stomach ache, hypertension & 1 & 0 \\
\hline 26 & $\begin{array}{l}\text { Peltophorum pterocarpum } \\
\text { (DC.) Backer ex Heyne } \\
\text { (Fabaceae - Calsalpinaceae) }\end{array}$ & Copperpod & $\begin{array}{l}\text { Leaves used to treat pain at child } \\
\text { birth }\end{array}$ & 0 & 2 \\
\hline 28 & $\begin{array}{l}\text { Persia americana Mill. } \\
\text { (Lauraceae) }\end{array}$ & Avocado pear & Hypertension & 1 & 7 \\
\hline 29 & $\begin{array}{l}\text { Psidium guajava L. } \\
\text { (Myrtaceae) }\end{array}$ & Guava & Leaves used as antimalarial & 8 & 28 \\
\hline 30 & $\begin{array}{l}\text { Spondias mombin L. } \\
\text { (Anacardiaceae) }\end{array}$ & Hug plum & Chest pain, antiaging & 1 & 1 \\
\hline 31 & $\begin{array}{l}\text { Spondias cytherea L. } \\
\text { (Anacardiaceae) }\end{array}$ & Golden apple & Antiaging & 0 & 2 \\
\hline 32 & $\begin{array}{l}\text { Senna fistula L. } \\
\text { (Caesalpinaceae) }\end{array}$ & Indian laburnum & Skin infections and laxatives & 0 & 4 \\
\hline 33 & Senna spp. (Caesalpinaceae) & - & Laxatives & 0 & 1 \\
\hline 34 & $\begin{array}{l}\text { Terminalia superba Engl. \& } \\
\text { Diels (Combretaceae) }\end{array}$ & Limba, Afara & $\begin{array}{l}\text { Stem bark used for treatment of } \\
\text { malaria }\end{array}$ & 0 & 1 \\
\hline 35 & $\begin{array}{l}\text { Terminalia mantaly H. Perrier } \\
\text { (Combretaceae) }\end{array}$ & Button tree & Ornamental & 8 & 1 \\
\hline 36 & $\begin{array}{l}\text { Terminalia catappa L. } \\
\text { (Combretaceae) }\end{array}$ & Almond fruit & $\begin{array}{l}\text { Fruits edible and leaves boiled } \\
\text { for malaria }\end{array}$ & 30 & 30 \\
\hline \multirow[t]{2}{*}{37} & $\begin{array}{l}\text { Terminalia ivorensis A. Chev. } \\
\text { (Combretaceae) }\end{array}$ & Black afara & $\begin{array}{l}\text { Stem bark used for treatment of } \\
\text { malaria }\end{array}$ & 0 & 2 \\
\hline & Total & & & 499 & 438 \\
\hline
\end{tabular}

RA - residential area; NRA - non-residential area

Source: Field survey, 2014

TABLE 2. Species richness of ethno-medicinal trees (Margalef's index $-D_{m g}$ )

\begin{tabular}{lccccc}
\hline \multicolumn{1}{c}{ Land use type } & S & S-1 & N & InN & D $_{\text {mg }}=(\mathrm{S}-1) / \operatorname{lnN}$ \\
\hline Residential area & 26 & 25 & 499 & 6.2126 & 4.0240 \\
Non-residential area & 29 & 28 & 438 & 6.0822 & 4.6035 \\
\hline
\end{tabular}

$\mathrm{S}$ - number of species; $\mathrm{N}$ - total number of individuals encountered; In - natural logarithms (base e); $\mathrm{D}_{m q}$ - Margalef's index

Source: Field survey, 2014

major roads from Delta Park entrance to the University Teaching Hospital (UPTH) road. A. indica was used as an avenue tree in the study area, while Mangifera indica L. was prominent within the residential area. Terminalia catappa L. spread across the two areas because of its role in shade provision during hot weather, while
Psidium guajava L. was more frequent in the non-residential area.

\section{The Nearest Neighbour Analysis}

The pattern of spread of ethno-medicinal trees through the use of the nearest neighbour analysis is shown in Table 4. The nearest neighbour 
TABLE 3. Species diversity (Shannon and Wiener's diversity index) of ethno-medicinal tree in University of Port Harcourt, Nigeria

\begin{tabular}{|c|c|c|c|c|c|c|c|c|c|}
\hline & \multirow{2}{*}{ Species } & \multicolumn{4}{|c|}{ Residential area } & \multicolumn{4}{|c|}{ Non-residential area } \\
\hline & & $S$ & pi & In pi & pi $\ln (p i)$ & $S$ & pi & In pi & pi $\ln (p i)$ \\
\hline 1 & Annona muricata & 0 & 0 & 0 & 0 & 2 & 0.0045 & -5.4036 & -0.0243 \\
\hline 2 & Anacardium occidentale & 19 & 0.0380 & -3.2701 & -0.1242 & 14 & 0.0319 & -3.4451 & -0.1098 \\
\hline 3 & Anthocleista vogelii & 1 & 0.0020 & -6.2146 & -0.0124 & 0 & 0 & 0 & 0 \\
\hline 4 & Azadirachta indica & 172 & 0.3446 & -0.0653 & -0.3671 & 61 & 0.1392 & -1.9718 & -0.2744 \\
\hline 5 & Bambussa vulgaris & 2 & 0.0040 & -5.5214 & -0.0220 & 0 & 0 & 0 & 0 \\
\hline 6 & Bauhinia tomentosa & 1 & 0.0020 & -6.2146 & -0.0124 & 0 & 0 & 0 & 0 \\
\hline 7 & Borassus aethiopum & 3 & 0.0060 & -5.1159 & -0.0306 & 12 & 0.0273 & -3.6008 & -0.0983 \\
\hline 8 & Chrysophyllum albidum & 2 & 0.0040 & -5.5214 & -0.0220 & 9 & 0.0205 & -3.8873 & -0.0796 \\
\hline 9 & Citrus limon & 7 & 0.0140 & -4.2686 & -0.0597 & 3 & 0.0068 & -4.9908 & -0.0339 \\
\hline 10 & Citrus reticulata & 1 & 0.0020 & -6.2146 & -0.0124 & 0 & 0 & 0 & 0 \\
\hline 11 & Citrus sinensis & 25 & 0.0501 & -2.9937 & -0.1499 & 19 & 0.0433 & -3.1396 & -0.1359 \\
\hline 12 & Citrus paradisi & 0 & 0 & 0 & 0 & 5 & 0.0114 & -4.4741 & -0.0510 \\
\hline 13 & Croton zambesicus & 1 & 0.0020 & -6.2146 & -0.0124 & 13 & 0.0296 & -3.5199 & -0.1041 \\
\hline 14 & Delonixregia & 17 & 0.0340 & -3.3813 & -0.1149 & 14 & 0.0319 & -3.4451 & -0.1098 \\
\hline 15 & Elaeis guineensis & 79 & 0.1583 & -1.8432 & -0.2917 & 88 & 0.2009 & -1.6049 & -0.3224 \\
\hline 16 & Eucalyptus camaldulensis & 34 & 0.0681 & -2.6867 & -0.1829 & 27 & 0.0616 & -2.7870 & -0.1716 \\
\hline 17 & Ficus exasperata & 1 & 0.0020 & -6.2146 & -0.0124 & 0 & 0 & 0 & 0 \\
\hline 18 & Ficus mucoso & 0 & 0 & 0 & 0 & 2 & 0.0045 & -5.4036 & -0.0243 \\
\hline 19 & Ficus sur & 0 & 0 & 0 & 0 & 1 & 0.0022 & -6.1192 & -0.0134 \\
\hline 20 & Gmelina arborea & 10 & 0.0200 & -3.9120 & -0.0782 & 8 & 0.0182 & -4.0063 & -0.0792 \\
\hline 21 & Hura crepitans & 12 & 0.0240 & -3.7297 & -0.0895 & 32 & 0.0730 & -2.6172 & -0.1910 \\
\hline 22 & Irvingia gabonensis & 2 & 0.0040 & -5.5214 & -0.0220 & 0 & 0 & 0 & 0 \\
\hline 23 & Mangifera indica & 60 & 0.1202 & -2.1185 & -0.2546 & 45 & 0.1027 & -2.2759 & -0.2337 \\
\hline 24 & Milicia excelsa & 0 & 0 & 0 & 0 & 4 & 0.0091 & -4.6994 & -0.0427 \\
\hline 25 & Moringa oleivera & 1 & 0.0020 & -6.2146 & -0.0124 & 0 & 0 & 0 & 0 \\
\hline 26 & Musanga cecropioides & 1 & 0.0020 & -6.2146 & -0.0124 & 0 & 0 & 0 & 0 \\
\hline 26 & Peltrophorum pterocarpum & 0 & 0 & 0 & 0 & 2 & 0.0045 & -5.4036 & -0.0243 \\
\hline 28 & Persia americana & 1 & 0.0020 & -6.2146 & -0.0124 & 7 & 0.0159 & -4.1414 & -0.0658 \\
\hline 29 & Psidium guajava & 8 & 0.0160 & -4.1351 & -0.0661 & 28 & 0.0639 & -2.7504 & -0.1757 \\
\hline 30 & Spondias mombin & 1 & 0.0020 & -6.2146 & -0.0124 & 1 & 0.0022 & -6.1192 & -0.0134 \\
\hline 31 & Spondias cytherea & 0 & 0 & 0 & 0 & 2 & 0.0045 & -5.4036 & -0.0243 \\
\hline 32 & Senna fistula & 0 & 0 & 0 & 0 & 4 & 0.0091 & -4.6994 & -0.0427 \\
\hline 33 & Senna spp. & 0 & 0 & 0 & 0 & 1 & 0.0022 & -6.1192 & -0.0134 \\
\hline 34 & Terminalia superba & 0 & 0 & 0 & 0 & 1 & 0.0022 & -6.1192 & -0.0134 \\
\hline 35 & Terminalia mantaly & 8 & 0.0160 & -4.1351 & -0.0661 & 1 & 0.0022 & -6.1192 & -0.0134 \\
\hline 36 & Terminalia catappa & 30 & 0.0601 & -2.8117 & -0.1689 & 30 & 0.0684 & -2.6823 & -0.1834 \\
\hline 37 & Terminalia ivorensis & 0 & 0 & 0 & 0 & 2 & 0.0045 & -5.4036 & -0.0243 \\
\hline & Total & 499 & & & 2.2220 & & 438 & & 2.6981 \\
\hline
\end{tabular}

$\mathrm{S}$ - number of individuals; pi - proportion of individuals belonging to the i-th species calculated as pi $=\mathrm{S} / \mathrm{N} ; \mathrm{N}$ - total number of all individuals in the sample; In - natural logarithms (base e)

Source: Field Data analysis, 2014 
TABLE 4. Nearest neighbour analysis

\begin{tabular}{lccl}
\multicolumn{1}{c}{ Land use } & Nearest neighbour ratio & z score & Decision \\
\hline Residential area & 0.30 & -0.30 & Clustered \\
Non-residential area & 0.42 & -23.06 & Clustered \\
\hline
\end{tabular}

Source: Field Data analysis, 2014

ratios of ethno-medicinal trees were 0.30 and 0.42 in the residential and non-residential area respectively.

The z-score revealed standard deviation of -0.30 in the residential land use type and -23.06 in the non-residential land use type. It may be inferred that the distribution pattern of ethnomedicinal trees in both residential and nonresidential land use was clustered. This analysis shows the plants' locations in Figure 3, while the pattern may be due to the same environmental quality functions (avenue and shading functions) of the ethno-medicinal trees.

\section{DISCUSSION}

Different land use forms have a significant effect on the species composition and diversity of flora resources of an ecosystem. The results from the study indicate high species diversity for the two land use forms with remarkable differences in the composition. Barbour et al. [25] noted that a large index value indicates greater species diversity; an index value above 2 is regarded as medium to high species diversity. Ethno-medicinal tree species diversity in the built up areas (RAs - 2.22 and NRAs - 2.69) are higher than 2 in the University Park, the University of Port Harcourt. It can then be rationally regarded high. Higher species composition of ethno medicinal tress in the RAs (499) may be due to the conservation measures of the residents by the cultivation and protecting of the trees. Larinde and Oladele [26] reported that the residents of the University of Port Harcourt plant and protect medicinal and fruit bearing trees in their homesteads. The culture of conserving frequently used medicinal plants in home gardens and traditional healers' premises were equally observed in south western Nigeria [27] in similar studies. Commonly used plant species are cultivated around residential areas for easy access and utilization. A. indica (172) and $M$. indica (60) are frequently employed in the treatment of malaria in tropical West Africa; this may be associated with the abundance of the two tree species in the RAs, since malaria has been reported to be the most prevailing disease among the poor population of the developing countries in West Africa [28]. A. indica contained Gedunin (seed oil), Nimbolide (leaves) and Azadirachtin (stem bark) as the active chemical compounds that inhibit the effect of malaria parasite Plasmodium berghei. $M$. indica contained1,2-benzenedicarboxylic acid that has antimalarial properties [29-31], and therefore they are planted in the RAs to meet the local needs as an antimalarial among the low income earners. Of the 499 plant population recorded in the RAs, ethno-medicinal tree species such as Elais guineensis Jacq. (79), M. indica (60), Citrus spp. (33), T. catappa (30) and Anacardium occidentale L. (19) have multiple uses: in the local medicine, in food provision, in generating additional household cash income and in providing environmental services. Dau and Elisha [32] noted the species abundance of plants with multiple usages in farmlands among farmers in Bauchi state of Nigeria. Abundant species in the NRAs comprise of ornamental and shade providing plants, and the species with massive branching habits observed in the survey include Hura crepitans L. (32), M. indica (45), P. guajava (28), T. catappa (30), Delonix regia (Boj. ex Hook.) Raf. (14), A. occidentale (14), Crotom zambesicus Müll.-Arg. (13) and Terminalia mantaly H.Perrier (8). Besides the beautification of the university landscape, shade provision is an essential service provided 
by the trees during hot tropical weather. People enjoy the cool breeze from the trees in sunny days to ease the tension, while the students are usually clustered around the trees for relaxation during extreme hot weather periods for stress relief. There are a lot of references on positive psychological and physiological effects of urban forests such as the stress reduction, and anxiety and depression management [33, 34].

An adequate understanding of the ecological indices of an ecosystem could provide better management approach for sustainable utilization of tree resources, especially in urban centres. Also, species diversity in a land use form determines the functioning of such area; RAs in the study is richer than NRAs in composition as a result of the functions thereof due to its ability to support livelihood and traditional healthcare. However, the tree diversity in NRAs possesses the potential for ecological restoration, unlike the RAs in the study. The z-score of the nearest neighbour analysis revealed a clustered arrangement of ethno-medicinal trees in the study. This is an indication that the trees were purposely arranged to satisfy a dual function of shade or fruits bearing and of landscape beautification, and therefore they are located close to buildings or as avenue trees, as revealed in Figure 3. The collection of plant parts for local medicine is usually done without permission from the university management, while stem barks and leaves are in most cases harvested indiscriminately without recourse to the survival of the plants. The total and unsustainable removal of $A$. indica and $M$. indica stem barks around the breast height have sometimes resulted in the death of many stands of these species.

\section{CONCLUSION}

Changes in land use/cover have a direct impact on ecosystem services in many ways, such as on the flora and fauna diversity, the products and services for human survival and the environmental balance. This study has confirmed the capacity of GIS to map ethno-medicinal trees. The species composition was higher in the residential area, while the species diversity was higher in the non-residential area. It is therefore recommended that there is need for periodic monitoring and assessment of ethno-medicinal trees in the study area for effective management and sustainable utilization. The monitoring should include other land use along with a public awareness campaign and the training of the residents on conservation measures for adequate knowledge of ethno-medicinal trees conservation. The training on the identification of ethno-medicinal trees, and the deliberate planting of other ethno-medicinal plants should be encouraged and the existing ones should be maintained by agencies concerned.

\section{REFERENCES}

1. ADEDEJI GA, AIYELOJA AA, OMOKHUA GE 2014 Occurrence and Severity of Ganoderma lucidum (Fr.) P. Karst. on Azadirachta indica Trees in University of Port Harcourt, Nigeria: Implications for Sustainable Harvesting and Replacement. Nat Sci 12 (8): 123-128

2. DWYER MC, MILLER RW 1999 Using GIS to assess urban tree canopy benefits and surrounding green space distributions. Journal of Arboriculture 25 (2): 102-107
3. ELUDOYIN OS, UTANG PB 2010 Geographical Information System: A Useful Tool in Urban Forestry. In: ljeomah HM, Aiyeloja AA (eds) Practical Issues in Forest and Wildlife Resources Management. Green Canopy Consultants Choba, Port Harcourt, Nigeria, pp 338-351

4. AJEWOLE OI 2010 Urban Forestry Development in Britain and Ireland: Lessons for Nigeria. In Adeyoju SK, Bada SO (eds) Readings in Sustainable Tropical Forest Management. Zenith Book house, Ibadan, Nigeria, pp 1-22 
5. DURUGBO EU, OYETORAN BO, OYEJIDE NE 2012 Vegetation inventory of the Redemption Camp, Ogun State, Nigeria; Evaluation of medicinal plant resources and strategies for conservation. $J$ Biol Sci 12 (1): 34-42. DOI: http://dx.doi.org/10.3923/ jbs.2012.34.42

6. WORLD HEALTH ORGANIZATION 2002 WHO Traditional Medicine Strategy 2002-05. World Health Organization, Geneva, Switzerland, 61 p. URL: http://www.wpro.who.int/health technology/book who traditional medicine strategy 2002 2005.pdf (5 November 2014)

7. DAMBATTA SH, ALIYU BS 2011 A survey of major ethno medicinal plants of Kano North, Nigeria, their knowledge and uses by traditional healers. Bayero Journal of Pure and Applied Sciences 4 (2): 28-34. DOI: http://dx.doi.org/10.4314/bajopas. $\underline{\mathrm{v} 4 \mathrm{i} 2.6}$

8. NWAUZOMA AB, DAPPA MS 2013 Ethnobotanical Studies of Port Harcourt Metropolis, Nigeria ISRN Botany 2013: 1-11. DOI: http://dx.doi. org/10.1155/2013/829424

9. WAHAB OM, AJALA OO, OJO MO, EGUNJOBI AJ 2013 Ethnomedicinal and Phytochemical Profile of Spilanthesfilicaulis (Schum. \& Thonn.) C.D Adams (Asteraceae) In Ibadan Metropolis. Healing Herbs Practice and Technology 2: 13-18.

10. NOWAK DJ 1993 Atmospheric carbon reduction by urban trees. J Environ Manage 37 (3): 207-217. DOI: http://dx.doi.org/10.1006/jema.1993.1017

11. WOOD JP 1999 Tree Inventories and GIS in Urban Forestry. MSc thesis, Faculty of the Virginia Polytechnic Institute and State University, Blacksburg, Virginia, $34 \mathrm{p}$

12. MILLER RW 1997 Urban Forestry: Planning and Managing Urban Greenspaces. Prentice Hall, Upper Saddle River, NJ, USA, $512 \mathrm{p}$

13. GOODWIN DW 1996 A street tree inventory for Massachusetts using a geographic information system. Journal of Arboriculture 22 (1): 19-28

14. AMUSA TO, JIMOH SO, ARIDANZI P, HARUNA M 2010 Ethnobotany and Conservation of Plant Resources of Kainji Lake National Park, Nigeria. Ethnobotany Research \& Applications 8: 181-194

15. ONI PI 2010 Ethnobotanical survey of a fallow plot for medicinal plants diversity in Idena village ljebu-Ode, South-western Nigeria. J Med Plants Res 4 (7): 509-516
16. AJIBESIN KK 2012 Ethno-botanical survey of plants used for skin diseases and related ailments in Akwalbom State, Nigeria. Ethnobotany Research \& Applications 10: 463-522

17. JIMOH SO, ADEBISI LA, IKYAAGBA ET 2009 Biodiversity and ethnobotanical potentials of plant species of University of Agriculture Makurdi Wildlife Park and Ikwe Games Reserve, Benue State, Nigeria. International Journal of Biological and Chemical Sciences 3 (6): 1375-1385. DOI: http://dx.doi.org/10.4314/ijbcs.v3i6.53157

18. ADNAN M 2011 Diversity and Abundance of Medicinal Plants among Different Forest-Use Types of the Pakistani Himalaya. PhD Thesis, University of Göttingen, Faculty of Forest Sciences and Forest Ecology, Göttingen, Germany, $108 p$

19. BELDA A, ZARAGOZÍ BB, MARTÍNEZ IJE, SEVA E 2013 Traditional Knowledge of Medicinal Plants in the Serra De Mariola Natural Park, SouthEastern Spain. African Journal of Traditional and Complementary Alternative Medicine 10 (2): 299-309. DOI: http://dx.doi.org/10.4314/ajtcam. v10i2.15

20. SHANNON CE, WEAVER W 1949 The mathematical theory of communication. University of Illinois Press, Urbana, IL, USA, $144 \mathrm{p}$

21. SPELLERBERG IF, FEDOR PJ 2003 A tribute to Claude Shannon (1916-2001) and a plea for more rigorous use of species richness, species diversity and the 'Shannon-Wiener' Index. Global Ecol Biogeogr 12 (3): 177-179. DOI: http://dx.doi. org/10.1046/j.1466-822X.2003.00015.x

22. MARGALEF R 1958 Temporal succession and spatial heterogeneity in phytoplankton. In: Buzzati-Traverso AA (ed) Perspectives in Marine Biology. University of California Press, Berkeley, CA, USA, pp 323-347

23. PIELOU EC 1975 Ecological diversity. John Wiley \& Sons, New York, NY, USA, $165 \mathrm{p}$

24. MAGURRAN AF 1988 Ecological Diversity and its Measurement. Princeton University Press, Princeton, NJ, USA, $179 p$

25. BARBOUR M, BURK JH, PITTS WD, GILLIAM FS, SCHWARTZ MW 1999 Terrestrial Plant Ecology. Benjamin/Cummings, Menlo Park, CA, USA, $634 \mathrm{p}$

26. LARINDE SL, OLADELE AT 2014 Edible Fruit Trees Diversity in a Peri-Urban Centre: Implications for Food Security and Urban Greening. Journal of Environment and Ecology 5 (2): 234-248. DOI: http://dx.doi.org/10.5296/jee.v5i2.6847 
27. OLADELE AT, ALADE GO, OMOBUWAJO OR 2011 Medicinal plants conservation and cultivation by traditional medicine practitioners (TMPs) in Aiyedaade Local Government Area of Osun State, Nigeria. Agriculture and Biology Journal of North America. 2 (3): 476-487

28. OKONKO IO, SOLEYE FA, AMUSAN TA, OGUN AA, UDEZE AO, NKANG AO, EJEMBI J, FALEYE TOC 2009 Prevalence of malaria plasmodium in Abeokuta, Nigeria. Malaysian Journal of Microbiology 5 (2): 113-118

29. KUMAR PS, MISHRA D, GHOSH G, PANDA CS 2010 Biological action and medicinal properties of various constituent of Azadirachtaindica (Meliaceae)" an Overview. Ann Biol Res 1 (3): 2434

30. AKIN-OSANAIYE BC, NOK AJ, IBRAHIM S, INUWA HM, ONYIKE E, AMLABU E, HARUNA E 2013 Antimalarial Effect of Neem Leaf and Neem Stem Bark Extracts on Plasmodium berghei Infected in The Pathology and Treatment of Malaria. International Journal of Research in Biochemistry and Biophysics 3 (1): 7-14
31. MADAN K, SHUKLA DS, TRIPATHI R, TRIPATHI A, SINGH R, DWIVEDI HD 2014 Isolation of three chemical constituents of Mangifera indica wood extract and their characterization by some spectroscopic techniques. International Journal of Emerging Technologies in Computational and Applied Sciences 14 (367): 217-218

32. DAU JH, ELISHA A 2013 Survey on Non-Timber Forest Products in Bauchi South Senatorial Districts, Bauchi State, Nigeria. Journal of Research in Forestry, Wildlife and Environmental 6 (1): 8297

33. PARK BJ, TSUNETSUGU Y, KASETANI T, KAGAWA T, MIYAZAKI Y 2010 The physiological effects of Shinrin-yoku (taking in the forest atmosphere or forest bathing): evidence from field experiments in 24 forests across Japan. Environmental Health and Preventive Medicine 15 (1): 18-26. DOI: http:// dx.doi.org/10.1007/s12199-009-0086-9

34. SHIN YK, KIM DJ, JUNG-CHOI K, SON YJ, KOO JW, MIN JA, CHAE JH 2013 Differences of psychological effects between meditative and athletic walking in a forest and gymnasium. Scand J Forest Res 28 (1): 64-72. DOI: http://dx.doi.org/10.1080/028275 $\underline{81.2012 .706634}$

(C) 2015 by the Croatian Forest Research Institute. This is an Open Access paper distributed under the terms of the Creative Commons Attribution License (http://creativecommons.org/licenses/by/4.0). 